\title{
Erratum to: Liquefaction potential evaluation of the quaternary alluvium, Western Ankara (Turkey)
}

\author{
Koray Ulamiş • Recep Kiliç
}

Published online: 26 February 2012

(C) Springer-Verlag 2012

\section{Erratum to: Environ Earth Sci}

\section{DOI 10.1007/s12665-012-1526-1}

In the original publication of the article, one of the reference citations contains an error. The corrected reference citation and the reference are given below:

On page 1 (under "Introduction", 11th line) "Kockar et al. (2008, 2009)" should be "Kockar and Akgun (2008) and Kockar et al. (2010)".

On page 14, the reference "Kockar MK, Akgun H, Rathje EM (2009) Evaluation of site conditions for the Ankara Basin of Turkey based on seismic site characterization of near surface geologic materials. Soil Dyn Earthq Eng. doi: 10.1016/j.soildyn.2009.05.007" should be "Kockar MK, Akgun H, Rathje EM (2010) Evaluation of site conditions for the Ankara Basin of Turkey based on seismic site characterization of near surface geologic materials. Soil Dyn Earthq Eng 30(1-2):8-20”.

The online version of the original article can be found under doi:10.1007/s12665-012-1526-1.

K. Ulamiş $(\bowtie) \cdot$ R. Kiliç

Department of Geological Engineering, Faculty of Engineering,

Ankara University, 06100 Tandogan, Ankara, Turkey

e-mail: ulamis@ankara.edu.tr

R. Kiliç

e-mail: rkilic@eng.ankara.edu.tr 